\title{
ANTI-DIABETIC AND RENO-PROTECTIVE EFFECT OF THE ETHANOLIC EXTRACT OF SOLANUM INDICUM IN ALLOXAN-INDUCED DIABETIC RATS
}

\author{
Raktim Borgohain1, Pradumna Pathak2, Roopshekhar Mohan ${ }^{3}$ \\ ${ }^{1}$ Assistant Professor, Department of Pharmacology, FAAMCH, Barpeta. \\ ${ }^{2}$ Demonstrator, Department of Pharmacology, FAAMCH, Barpeta. \\ ${ }^{3}$ Assistant Professor, Department of Community Medicine, FAAMCH, Barpeta.
}

\begin{tabular}{l}
\hline ABSTRACT \\
BACKGROUND \\
The objective of the present study was to investigate the anti-diabetic and renoprotective activity of Solanum indicum in alloxan- \\
induced diabetic rat.
\end{tabular}

\section{MATERIALS AND METHODS}

Ethanolic extract of Solanum indicum was administered orally at a dose of $100 \mathrm{mg} / \mathrm{kg}$. Blood glucose levels were measured by glucose oxidase method on weekly intervals for 4 weeks. Urine samples were collected before the induction of diabetes and at the end of 8 weeks of treatments and analysed for urine volume, urinary protein and creatinine levels.

Statistical analysis - Data were statistically analysed using one-way ANOVA test followed by Dunnet's multiple comparison test. A p value $<0.05$ was considered significant. Data were presented as mean \pm standard error of mean.

\section{RESULTS}

Solanum indicum showed significant anti-diabetic effect $(\mathrm{p}<0.05)$, but the efficacy was lower than standard drug Glibenclamide. Significant renoprotective activity was observed in Solanum indicum treated rats.

\section{CONCLUSION}

It can be concluded that the fruit extract of Solanum indicum possess significant anti-diabetic and renoprotective activity in animal model.

KEYWORDS: Diabetes, Glucose Oxidase Method, Glibenclamide.

HOW TO CITE THIS ARTICLE: Borgohain R, Pathak P, Mohan R. Anti-diabetic and reno-protective effect of the ethanolic extract of solanum indicum in alloxan-induced diabetic rats. J. Evolution Med. Dent. Sci. 2016;5(99):7294-7297, DOI: $10.14260 /$ jemds $/ 2016 / 1650$

\section{BACKGROUND}

Diabetes mellitus is a clinical syndrome characterised by an increase in plasma blood glucose (hyperglycaemia). Diabetes has many causes, but is most commonly due to type 1 or type 2 diabetes. Type 1 diabetes is caused by autoimmune destruction of pancreatic beta cells resulting in absolute insulin deficiency, whereas type 2 diabetes is characterised by resistance to insulin and failure to produce sufficient insulin. Globally, it is estimated that 366 million people had diabetes in 2011 and this figure is expected to reach 522 million by 2030.(1) Since the discovery of insulin, several synthetic Oral Hypoglycaemic Drugs (OHD) are available in the market, but these synthetic drugs are not sufficient to treat diabetes, particularly type 2 . In this respect, our traditional herbal medicine can act as an alternative to synthetic drugs. Generally, these phytochemicals have fewer side effects. Many of them are helpful in preventing complications like diabetic nephropathy, retinopathy or neuropathy.(2) Solanum indicum

Financial or Other, Competing Interest: None.

Submission 19-11-2016, Peer Review 05-12-2016,

Acceptance 07-12-2016, Published 12-12-2016.

Corresponding Author:

Dr. Raktim Borgohain,

Assistant Professor,

Department of Pharmacology,

FAAMCH, Barpeta, Assam.

E-mail: borgohainraktim@yahoo.com

DOI: $10.14260 /$ jemds/2016/1650 belongs to the family Solanaceae. It is a bushy herb containing prickly spikes in the stem and available throughout India and all over the tropical and subtropical regions of the world.(3) Traditionally, the plant roots are used as diaphoretic, diuretic, expectorant and stimulant. The root is used against bronchitis, itches and for body aches. Their juice has been used for ringworm, gout and earache.(4) Since the fruits are traditionally used in diabetes and kidney aliments in folklore medicine in Northeast India, the current study was undertaken to verify these facts experimentally.

\section{MATERIALS AND METHODS}

Plant Material

Fresh seeds of Solanum indicum were purchased from the local traders and shade dried to obtain a completely dried product, the voucher specimen FA 273/16 was deposited in herbarium of the Department of Pharmacology.

\section{Extraction \\ As per the method of percolation described by Remington,(5) they were washed thoroughly and air dried on a drier table at room temperature. After crushing in mixer grinder, five hundred grams of the powered pulp were soaked in $90 \%$ ethyl alcohol and shifted to a percolator. The soaked powder was percolated after 24 hours of maceration. The residue obtained was put in a vacuum desiccator. Colour of the extract was dark green. It was dissolved in normal saline and was used in the experiment according to the methods of Satyavati, et al.(6)}




\section{Animal}

Male albino rats weighing about 125 - 150 grams maintained under standard experimental condition (Temperature $27 \pm$ $2^{\circ} \mathrm{C}$ and 12 hours light/dark cycle) were housed in standard environmental conditions. All the animal experiments were conducted according to guidelines recommended by the Committee for the Purpose of Control and Supervision of Experiments on Animals (CPCSEA).(7) The experimental protocols were approved and a written permission from Institutional Animal Ethical Committee has been taken to carry out and complete the study.

\section{Acute Toxicity Test}

Healthy albino rats of either sex starved overnight were divided into five groups and were orally fed with Ethanolic Solanum Indicum (ESI) extract in increasing dose. These rats were observed continuously for $2 \mathrm{hrs}$. for behavioural, neurological and autonomic profiles and after a period of 24 and $72 \mathrm{hrs}$. for any death (MN Ghosh).(8) It was observed that the test extract was not lethal to rats even at $1000 \mathrm{mg} / \mathrm{kg}$ dose. Hence, the dose of $100 \mathrm{mg} / \mathrm{kg}$ was arbitrarily selected. To contain the number of animals used in the experiment and to allay the concerns of Institutional Ethical Committee, single most probable dose of the extract was selected instead of multiple for the study.

\section{Induction of Diabetes}

Hyperglycaemia was induced by single intraperitoneal injection of alloxan monohydrate at a dose of $150 \mathrm{mg} / \mathrm{kg}$ body weight.(9) After 72 hours, animals were tested for hyperglycaemia using glucose oxidase method.

\section{Evaluation of Anti-Diabetic Activity}

Rats were divided into four groups of six animals each and drugs were given orally for four weeks as follows:

- Group I (Normal control group): Normal saline 5 $\mathrm{mL} / \mathrm{kg} /$ day

- Group II (Diabetic control group): Normal saline 5 $\mathrm{mL} / \mathrm{kg} /$ day
- Group III (Diabetic test group): ESI in normal saline 100 $\mathrm{mg} / \mathrm{kg} /$ day

- Group IV (Diabetic standard group): Glibenclamide in normal saline $25 \mathrm{mg} / \mathrm{kg} /$ day

\section{Blood Collection and Blood Glucose Estimation}

Blood samples were obtained from tail vein and blood glucose estimation was done by glucose oxidase method using glucose kit as per the method of Sood et al.(10)

\section{Evaluation of Renoprotective Action}

For renoprotective evaluation, rats were given daily treatment for 8 weeks. Same animals after evaluating antidiabetic activity were continued treatment for another 4 weeks. Renoprotective activity was assessed biochemically by determining urine volume, urinary protein and urinary creatinine. For urinary collection, rats were housed in metabolic cages at the start (pre-diabetic condition) and at the end ( $8^{\text {th }}$ week) of the experiment. Urine volume was measured by putting each rat in individual metabolic cage for 6 hours and volume of excreted urine was measured. Urine protein was measured according to Johnson et al.(11) Urinary creatinine was estimated by modified Jaffe's reaction.(12)

\section{Statistical Analysis}

Data were statistically analysed using one-way Anova test followed by Dunnet's multiple comparison test. A 'P' value < 0.05 was considered significant. Data were presented as mean \pm SEM (standard error of mean).

\section{RESULTS}

Results of anti-diabetic activity are summarised in Table 1. On comparing the ESI treated group and Glibenclamide treated group, the percentage of reduction of blood sugar level was $17.8 \%$ and $26.4 \%$ at the end of $1{ }^{\text {st }}$ week, $22.8 \%$ and $36.7 \%$ at the end of $2^{\text {nd }}$ week, $43.5 \%$ and $54.7 \%$ at the end of 3 rd week and $54.5 \%$ and $59.5 \%$ at the end of $4^{\text {th }}$ week respectively. These results are shown in Table 2 .

\begin{tabular}{|c|c|c|c|c|c|c|c|}
\hline Group & Treatment & Initial & $\begin{array}{c}\text { 72 hrs. after Diabetes } \\
\text { Induction }\end{array}$ & 1 $^{\text {st }}$ Week & 2 $^{\text {nd }}$ Week & 3 $^{\text {rd Week }}$ & 4 $^{\text {th }}$ Week \\
\hline A & Normal control & $99 \pm 0.2$ & $97 \pm 0.2$ & $98 \pm 0.3$ & $97 \pm 0.35$ & $96 \pm 0.4$ & $98 \pm 0.2$ \\
\hline B & Diabetic control & $96 \pm 0.3$ & $276 \pm 0.7^{\mathrm{a}}$ & $316 \pm 0.5^{\mathrm{a}}$ & $356 \pm 0.2^{\mathrm{a}}$ & $408 \pm 0.2^{\mathrm{a}}$ & $326 \pm 0.6^{\mathrm{a}}$ \\
\hline C & Alloxan + ESI & $97 \pm 0.2$ & $280 \pm 0.6^{\mathrm{a}}$ & $230 \pm 0.2^{\mathrm{b}}$ & $216 \pm 0.6^{\mathrm{b}}$ & $158 \pm 0.3^{\mathrm{b}}$ & $128 \pm 0.3^{\mathrm{b}}$ \\
\hline D & $\begin{array}{c}\text { Alloxan + } \\
\text { Glibenclamide }\end{array}$ & $98 \pm 0.4$ & $272 \pm 0.5^{\mathrm{a}}$ & $200 \pm 0.35^{\mathrm{b}}$ & $172 \pm 0.4^{\mathrm{b}}$ & $123 \pm 0.5^{\mathrm{b}}$ & $110 \pm 0.5^{\mathrm{b}}$ \\
\hline
\end{tabular}

Values are expressed as mean $\pm \mathrm{SEM}, \mathrm{a}=\mathrm{p}<0.05$ when compared to the normal control group, $\mathrm{b}=\mathrm{p}<0.05$ when compared to diabetic control group.

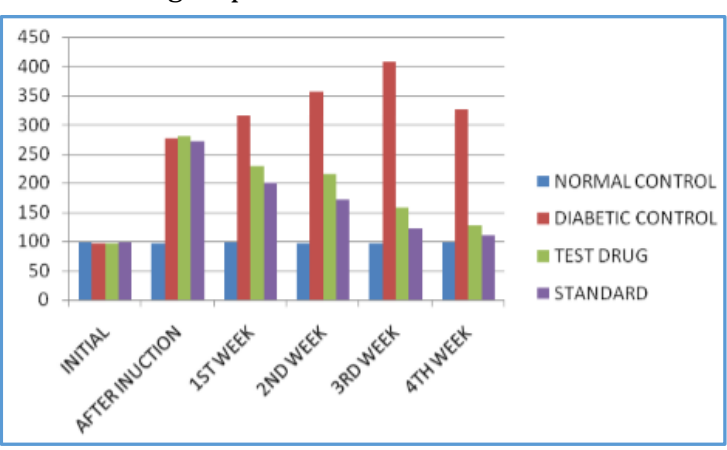

Figure 1. Effect of Solanum Extract on Blood Glucose Level in Alloxan-Induced Diabetic Rat
Alloxan-induced diabetic rats showed a significant ( $\mathrm{p}<$ 0.05 ) increase in urinary output, urinary protein and creatinine after 8 weeks as compared to their pre-diabetic levels. ESI and glibenclamide prevent the change in urine output, protein and creatinine.(13) Results of renoprotective activity are summarised in Table 2, Table 3, Table 4 respectively.

\begin{tabular}{|c|c|c|}
\hline Groups & o Week & 8 Weeks \\
\hline Normal Control (NC) & $4 \pm 0.23$ & $4.5 \pm 0.3$ \\
\hline Diabetic Control (DC) & $3.9 \pm 0.4$ & $12 \pm 0.4 \mathrm{a}$ \\
\hline ESI & $4.2 \pm 0.3$ & $5.6 \pm 1.2^{\mathrm{b}}$ \\
\hline Glibenclamide (GLIBEN) & $3.7 \pm 0.17$ & $4.6 \pm 0.9 b$ \\
\hline
\end{tabular}


$\mathrm{a}=\mathrm{p}<.05$ when compared with pre-diabetic value. $\mathrm{B}=\mathrm{p}<$ .05 when compared to diabetic control group.

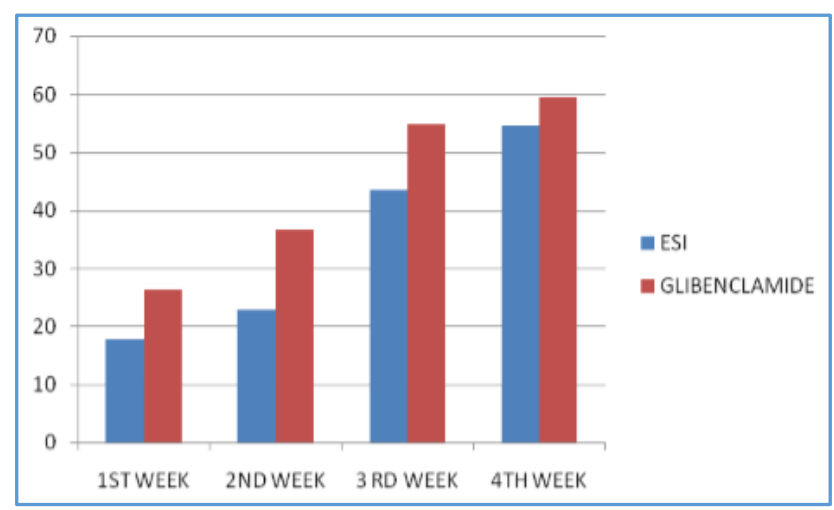

Figure 2. Percentage Reduction of Blood Sugar in ESI and Glibenclamide Treated Diabetic Rat

\begin{tabular}{|c|c|c|}
\hline Group & 0 Week & 8 Weeks \\
\hline Normal control & nil & nil \\
\hline Diabetic control & Nil & $1.8 \pm 0.16$ \\
\hline ESI & Nil & $0.9 \pm 0.14^{\mathrm{a}}$ \\
\hline Glibenclamide & nil & $0.7 \pm 0.3^{\mathrm{a}}$ \\
\hline \multicolumn{2}{|c|}{ Table 3: Effect of ESI on Urine Protein $(\mathbf{g m} / \boldsymbol{d L})$} \\
\hline
\end{tabular}

$\mathrm{a}=\mathrm{p}<.05$ when compared to diabetic control group.

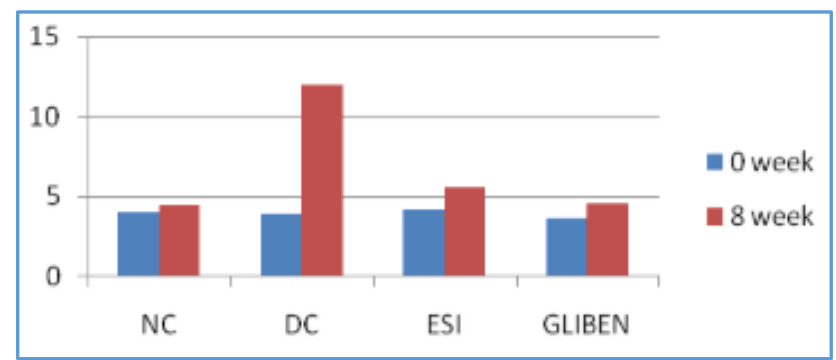

Figure 3: Effect of ESI on Urine Volume ( $\mathrm{mL} / 6$ hrs.)

\begin{tabular}{|c|c|c|}
\hline Group & 0 Week & 8 Weeks \\
\hline Normal control & $2.8 \pm 0.2$ & $2.7 \pm 0.4$ \\
\hline Diabetic control & $3 \pm 0.15$ & $9 \pm 0.35^{\mathrm{a}}$ \\
\hline ESI & $2.9 \pm 0.3$ & $4.1 \pm 0.6^{\mathrm{b}}$ \\
\hline Glibenclamide & $2.8 \pm 0.12$ & $3 \pm 0.29^{\mathrm{b}}$ \\
\hline \multicolumn{2}{|c|}{ Table 4: Effect of ESI on Urine Creatinine ( $\mathbf{m g} / \mathbf{2 4}$ hrs.) } \\
\hline
\end{tabular}

$\mathrm{a}=\mathrm{p}<.05$ when compared to pre-diabetic value. $\mathrm{b}=\mathrm{p}<.05$ when compared to diabetic control group.

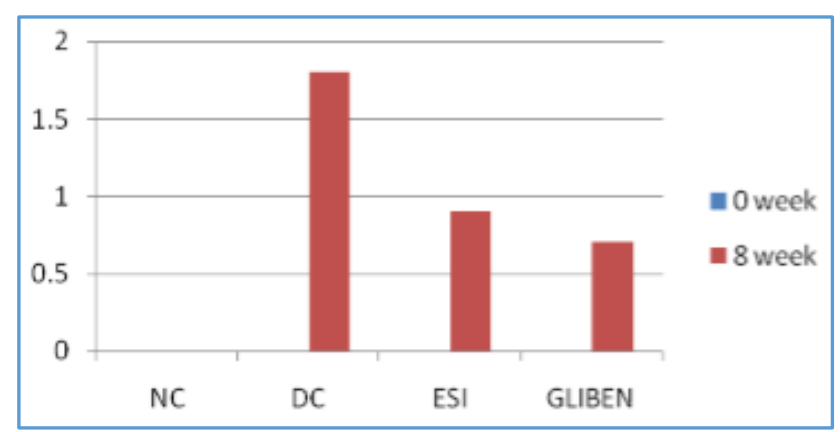

Figure 4: Effect of ESI on Urine Protein (gm/dL)

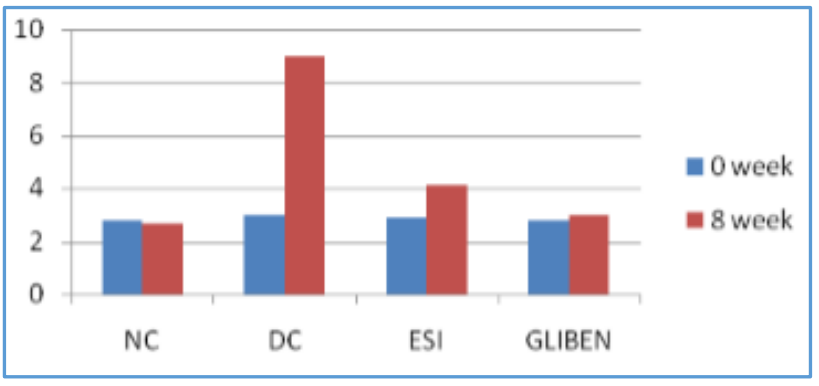

Figure 5. Effect of ESI on Urine Creatinine (mg/24 hrs.)

\section{DISCUSSION}

The aim of the study was to evaluate whether the fruit of Solanum indicum had anti-diabetic and renoprotective activity. It was found that the ethanolic extract of Solanum indicum lowered blood glucose levels in Alloxan-induced diabetic rats. The test drug given at a dose of $100 \mathrm{mg} / \mathrm{kg} /$ day orally for four weeks reduced blood sugar level significantly ( $p$ $<0.05$ ) in diabetic albino rat as compared to diabetic control group. Earlier studies found that nephropathic changes in diabetic rat observed after 8 weeks of induction of diabetes experimentally. $(14,15)$ Study of urine volume, urine protein and urine creatinine in diabetes-induced rat have indicated that there was no significant increase of these parameter in Solanum indicum treated group. However, in diabetes control group there was increase in urine output, urine protein and urine creatinine. The test drug treated group significantly reduced these parameters when compared with diabetic control group. The most probable reasons for this result may be due to the insulinomimetic properties or augmentation of insulin secretion by Solanum indicum. The experimental findings revealed that Solanum indicum more effectively inhibited the incidence of diabetic nephropathy, but further study is needed encompassing multiple doses of the extract and having more parameters of diabetes and diabetes-induced nephropathy like serum insulin level, histopathology of kidneys, free radical studies.

\section{CONCLUSIONS}

Considering the results obtained, it can be concluded that the fruit extract of Solanum indicum possess significant antidiabetic and renoprotective activity in animal model. However, further studies may be warranted to corroborate the present experimental finding.

\section{REFERENCES}

1. Pearson ER. Diabetes mellitus. Walker, colledge, ralston, penman. Davidson's principles and practice of medicine. 22nd edn. Churchill Livingstone Elsevier 2014:p 797.

2. Sarmah PC. Ethno antidiabetic plants of Assam. International Journal of Applied Biology and Pharmaceutical Technology 2011;2(4):246-51.

3. Kirtikar KR, Basu BD. Indian medicinal plants. $2^{\text {nd }}$ edn. Volume 2, International book publication distribution, Dehradun, India 1975:1755-7.

4. The ayurvedic pharmacopoeia of India. $1^{\text {st }}$ edn, part 1 , Volume 2. Delhi: ministry of health and family welfare, govt of India, the controller of publication, civil lines 1999:27-8.

5. Extraction and extractives. In: Remingtons pharmaceutical sciences. 14th edn. Mack Publishing company Easton Pennsylvania 1965:1578-93. 
6. Satyavati GV. Extracta liquida, pharmaceutical formulas. $11^{\text {th }}$ edn, Volume 1 . The chemist and druggist, WE 2, London 1950:183-4.

7. CPCSEA guidelines for laboratory animal facility. Committee for the purpose of control and supervision of experiments on animals. Indian $\mathrm{J}$ Pharmacol 2003;35:257-74.

8. Ghosh MN. Toxicity studies. Fundamentals of experimental pharmacology. $3^{\text {rd }}$ edn. Hilton and company, Kolkota 2005:p 190.

9. Kulkarni SK. Commonly used drugs, their doses and nature of action in laboratory animals. Delhi: Handbook of experimental pharmacology. $3^{\text {rd }}$ edn. Vallabh prakashan 2005:190-5.

10. Sood R. Clinical chemistry, blood sugar estimation, medical laboratory technology methods of interpretations. $5^{\text {th }}$ edn. Jaypee brothers medical publishers Ltd, New Delhi 1999:433-6.

11. Johnson MA, Rohlfs EM, Silverman LM. Determination of proteins in urine. In: Burtis CA, Ashwood ER. Teitz textbook of clinical chemistry. $3^{\text {rd }}$ edn. Philadelphia: WB Saunders 1999:525-6.

12. Newman DJ, Prince CP. Renal function and nitrogen metabolites. In: Burtis CA, Ashwood ER. Teitz textbook of clinical chemistry. $3^{\text {rd }}$ edn. Philadelphia: WB Saunders 1990:1204-10.

13. Elseweidy MM, Elswefy SE, Shawky M. Diabetic renal injury induced in experimental rats: role of curcuminoids as probable therapeutic agent. Biomedical Engineering Research 2013;2(4):175-81.

14. Vaishya R, Singh J, Lal H. Effect of irbesartan on streptozotocin induced diabetic nephropathy: an interventionary study. Indian journal of Clinical Biochemistry 2008;23(2):195-7.

15. Rao NK, Nammi S. Antidiabetic and renoprotective effects of the chloroform extract of terminalia cfebula retz. Seeds in streptozotocin induced diabetic rats. BMC Complement Altern Med 2006;6:17. 